\title{
Uji Sensitivitas Metode Sistem Pendukung Keputusan Dalam Menentukan Lokasi Penyebaran Media Promosi
}

\author{
Donny Fernando ${ }^{1}$, Nurfitri Handayani ${ }^{2}$ \\ ${ }^{1,2}$ Program Studi Sistem Informasi Fakultas Teknologi Informasi Universitas Serang Raya \\ Jln. Raya Cilegon Serang - Drangong Kota Serang \\ ${ }^{1}$ mr.donny2008@gmail.com \\ ${ }^{2}$ nurfitrihandayani69@gmail.com
}

\begin{abstract}
Abstrak - SMK Informatika Kota Serang adalah salah satu SMK di Kota Serang yang setiap tahun selalu melakukan promosi untuk mendapatkan peserta didik. Saat ini penyebaran media promosi dilakukan tanpa menggunakan sebuah metode yang terukur. Sehingga banyak media promosi yang terbuang sia-sia tanpa mendapatkan hasil yang tepat. Pada penelitian ini, peneliti mencoba melakukan penelitian metode pendukung keputusan apa yang paling tepat untuk menyelesaikan kasus ini. Peneliti mengusulkan 3 metode yaitu Weight Product (WP), Simple Additive Weight (SAW) dan Technique For Order Preference By Similarity To Ideal Solution (TOPSIS) yang dilakukan uji sensitivitas.
\end{abstract}

Kata Kunci- Uji Sensitivitas, Weight Product (WP), Simple Additive Weight (SAW) dan Technique For Order Preference By Similarity To Ideal Solution (TOPSIS), Sistem Pendukung Keputusan.

\section{Pendahuluan}

Saat ini proses untuk menentukan lokasi dalam penyebaran media promosi pada SMK Informatika kota Serang dilakukan tanpa menggunakan sebuah metode yang terukur, sehingga proses pengambilan keputusan kurang efektif.

Sistem Pendukung Keputusan (SPK) atau Decision Support System (DSS) adalah sebuah sistem yang mampu memberikan kemampuan pemecahan masalah maupun kemampuan pengkomunikasian untuk masalah dengan kondisi semi terstruktur dan tak terstruktur. Sistem ini digunakan untuk membantu pengambilan keputusan dalam situasi semi terstruktur dan situasi yang tidak terstruktur, dimana tak seorangpun tahu secara pasti bagaimana keputusan seharusnya dibuat (Turban, 2001).

SPK memiliki banyak metode untuk menyelesaikan sebuah permasalahan, pada kesempatan ini penulis ingin melakukan pengujian metode mana yang paling tepat untuk menyelesaikan kasus yang ada, sehingga diharapkan penelitian ini dapat menjadi referensi untuk penelitian berikutnya untuk menyelesaikan studi kasus yang sama.

Dalam beberapa penelitian, beberapa kasus yang sejenis diselesaikan dengan menggunakan metode yang berbeda sebagai referensi, penelitian yang dilakukan Sri Eniyati, Perancangan Sistem Pendukung Pengambilan Keputusan untuk Penerimaan Beasiswa dengan Metode SAW (Simple
Additive Weighting), Jurnal Teknologi Informasi DINAMIK Volume 16, No.2, Juli 2011 : 171- 176, ISSN : 0854- 9524, penelitian yang dilakukan oleh Perdana, Nuri Guntur and Widodo, Tri (2013) Sistem Pendukung Keputusan Pemberian Beasiswa Kepada Peserta Didik Baru Menggunakan Metode TOPSIS, Seminar Nasional Teknologi Informasi \& Komunikasi Terapan ISBN: 979-260266-6 dan penelitian yang dilakukan oleh Nency Nurjannah, Zainal Arifin, Dyna Marisa Khairina, 2015, Sistem Pendukung Keputusan Pembelian Sepeda Motor Dengan Metode Weighted Product, Jurnal Informatika Mulawarman.

Dengan adanya proses uji sensitivitas di sistemnya, maka akan memudahkan pengguna dalam memilih metode yang terbaik dan dengan adanya proses uji sensitivitas akan memberikan sebuah solusi yang tepat untuk menyelesaikan kasus multi-attribute decision making (MADM) dengan menggunakan metode yang sesuai.

Pada penelitian ini mengusulkan sebuah pendekatan sistem pendukung keputusan dalam memilih lokasi dalam penyebaran media promosi pada SMK Informatika Kota Serang, menggunakan sistem MADM dengan metode WP, SAW dan TOPSIS dilanjutkan dengan hasil dari 3 metode tersebut dilakukan proses uji sensitivitas terhadap kasus ini. 


\section{Metodologi Penelitian}

Bagian ini menjelaskan secara rinci tentang penelitian yang dilakukan.

Pada penelitian ini penulis menggunakan metode penelitian deskriptif, dimana penulis mengumpulkan data secara detail, mendalam dan juga actual. Adapun langkah-langkah yang digunakan adalah:

1. Studi literatur

Pada tahap ini dilakukan penggalian konsep penelitian melalui studi pustaka.

2. Wawancara

Pada tahap ini penulis melakukan wawancara dengan wakil kepala sekolah sekaligus sebagai kepala Penerimaan Peserta Didik Baru di SMK Informatika Kota Serang.

3. Observasi

Observasi dilakukan dengan pengamatan yang dilakukan pada beberapa lokasi kecamatan di Kota Serang melihat banyaknya media promosi yang tersebar.

\section{HASIL DAN PEMBAHASAN}

\section{A. Metode Weight Product (WP)}

Metode Weighted Product (WP) menggunakan perkalian untuk menghubungkan rating atribut, dimana rating setiap atribut harus dipangkatkan dulu dengan bobot atribut yang bersangkutan. Proses tersebut sama halnya dengan normalisasi. Metode Weighted Product ini lebih efisien karena waktu yang dibutuhkan dalam perhitungan lebih singkat.

$$
S_{i}=\prod_{j=1}^{n} x_{i j}{ }^{w_{j}}
$$

(1)

dengan $\mathrm{i}=1,2 \ldots \ldots . \mathrm{n}$, dimana $\Sigma \mathrm{W}_{\mathrm{j}}=1 \mathrm{~W}_{\mathrm{j}}$ adalah pangkat bernilai positif untuk atribut keuntungan, dan pangkat negatif untuk atribut biaya.

$$
W_{j}=\frac{\cdots}{\Sigma W_{j}}
$$

Preferensi relatif dari setiap alternatif, diberikan sebagai:

$$
V_{1}=\frac{\prod_{j=1}^{n} x_{j}{ }^{v_{j}}}{\prod_{j=1}^{n}\left(x_{j}^{*}\right)^{v_{j}}} \text { dengan } \mathrm{i}=1,2 \ldots . \mathrm{m}
$$

Untuk kriterianya terbagi dalam 2 kategori yaitu bernilai positif termasuk dalam kriteria keuntungan (benefit) dan yang bernilai negatif termasuk dalam kriteria biaya (cost)

\section{B. Metode Simple Additive Weight (SAW)}

Metode SAW sering juga dikenal istilah metode penjumlahan terbobot. Konsep dasar metode SAW adalah mencari penjumlahan terbobot dari rating kinerja pada setiap alternatif dari semua atribut. Metode SAW membutuhkan proses normalisasi matriks keputusan (X) ke suatu skala yang dapat diperbandingkan dengan semua rating alternatif yang ada.

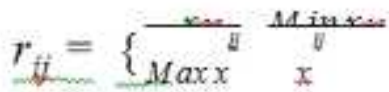

(4)

dimana:

- $\quad \mathrm{r}_{\mathrm{ij}}$ adalah nilai rating kinerja ternormalisasi.

- $\mathrm{x}_{\mathrm{ij}}$ adalah adalah nilai atribut yang dimiliki dari setiap kriteria.

- $\quad$ Max $x_{i j}$ adalah nilai terbesar dari setiap kriteria.

- $\quad$ Min $x_{\mathrm{ij}}$ adalah nilai terkecil dari setiap kriteria.

- benefit adalah jika nilai terbesar adalah terbaik.

- cost adalah jika nilai terkecil adalah terbaik

dimana $\mathrm{r}_{\mathrm{ij}}$ adalah nilai rating kinerja ternormalisasi dari alternatif Ai pada atribut $\mathrm{Cj}$;

$\mathrm{i}=1,2, . \mathrm{m}$ dan $\mathrm{j}=1,2, \ldots$. n. Nilai preferensi untuk setiap alternatif ( $\Sigma$ ) diberikan:

$$
V_{i}=\sum_{j=1}^{n} W_{i} r_{i j}
$$

Nilai $\mathrm{V}_{\mathrm{i}}$ yang lebih besar mengindikasikan bahwa alternatif lebih terpilih.

\section{Technique For Order Preference By Similarity To Ideal Solution (TOPSIS)}

TOPSIS adalah salah satu metode yang bisa membantu proses pengambilan keputusan yang optimal untuk menyelesaikan masalah keputusan secara praktis. Hal ini disebabkan karena konsepnya sederhana dan mudah dipahami, komputasinya efisien dan memiliki kemampuan untuk mengatur kinerja relatif dari alternatif-alternatif keputusan dalam bentuk matematis sederhana.

Secara umum, prosedur TOPSIS mengikuti langkahlangkah sebagai berikut :

1. Menentukan matriks keputusan yang ternormalisasi.

2. Menghitung matriks keputusan ternormalisasi yang terbobot. 
3. Menghitung matriks solusi ideal positif dan matriks solusi ideal negatif.

4. Menghitung jarak antara nilai setiap alternatif dengan matriks solusi ideal positif dan matriks solusi ideal negatif

5. Menghitung nilai preferensi untuk setiap alternatif TOPIS membutuhkan rating kinerja setiap alternatif Ai pada setiap kinerja $\mathrm{y}_{\mathrm{i}}^{+}$yang ternormalisasi, yaitu:

(6)

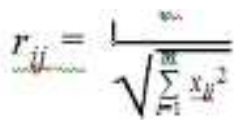

$\mathrm{i}=1,2, \ldots \mathrm{n}$ dan $\mathrm{j}=1,2, \ldots \mathrm{n}$

Solusi ideal positif $\mathrm{A}^{+}$dan solusi ideal negatif $\mathrm{A}^{-}$dapat ditentukan berdasarkan rating bobot ternormalisasi $\left(\mathrm{y}_{\mathrm{ij}}\right)$ sebagai berikut :

$$
Y_{\mathrm{L}}=W_{\mathrm{L}} r_{\mathrm{L}}
$$

(8)

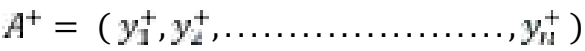

$$
A^{-}=\left(y_{1}^{-}, y_{2}^{-}, \ldots \ldots \ldots \ldots \ldots \ldots, y_{n}^{-}\right)
$$

(9)

dengan:

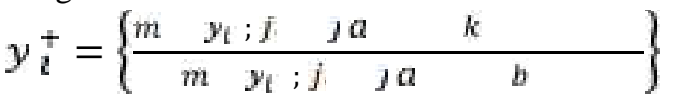

$$
y_{i}^{-}=\left\{\begin{array}{cccc}
m & y_{l} ; j & j a & k \\
\hline m \quad y_{l} ; i & j a & b
\end{array}\right\}
$$

Jarak antara alternatif $\mathrm{Ai}$ dengan solusi ideal positif dirumuskan sebagai berikut :

$$
D_{i}^{+}=\mathbf{\mathbf { d }} / \sum_{j=1}^{-}\left(y_{i}^{+}-y_{i j}\right)^{2}
$$

Jarak antara alternatif Ai dengan solusi ideal negatif dirumuskan sebagai berikut:

$$
D_{i}^{-}=\sqrt{\sum_{j=1}^{m}\left(y_{i j}-y_{i}^{-}\right)^{2}}
$$

Menentukan nilai preferensi untuk setiap alternatif:

$$
P_{1}=\frac{n}{n+i n}
$$

(14)

Nilai $\mathrm{V}_{\mathrm{i}}$ yang lebih besar menunjukkan bahwa alternatif $\mathrm{A}_{\mathrm{i}}$ lebih dipilih.

\section{Alternatif yang digunakan}

Alternatif yang digunakan merupakan nama sekolah dari data peserta didik sebelumnya yang telah banyak masuk ke SMK Informatika Kota Serang untuk penyebaran media promosi :

$$
\begin{array}{rll}
- & \text { A1 } & =\text { Cipocok Jaya } \\
- & \text { A2 } & =\text { Curug } \\
- & \text { A3 } & =\text { Kasemen } \\
- & \text { A4 } & =\text { Taktakan } \\
- & \text { A5 } & =\text { Walantaka } \\
- & \text { A6 } & =\text { Serang }
\end{array}
$$

\section{E. Kriteria / Atribut yang digunakan}

Kriteria yang digunakan pada sistem penunjang keputusan dalam pemilihan sekolah, yaitu :w

\begin{tabular}{|c|l|}
\hline Kode Kriteria & Nama Kriteria \\
\hline C1 & Jarak Tempuh \\
\hline C2 & Luas Wilayah \\
\hline C3 & Jumlah SLTP \\
\hline C4 & Biaya Transportasi \\
\hline C5 & Jumlah Peserta Didik SLTP \\
\hline
\end{tabular}

\section{F. Pembobotan Keputusan}

Berikut di bawah ini adalah pembobotan keputusan.

\begin{tabular}{|l|c|c|c|}
\hline \multicolumn{3}{|c|}{ Bobot Kriteria } \\
\hline Nama Kriteria & C1 & $30 \%$ & 0.3 \\
\hline Luak & C2 & $20 \%$ & 0.2 \\
\hline Jumlah SLTP & C3 & $20 \%$ & 0.2 \\
\hline Biaya Transportasi & C4 & $10 \%$ & 0.1 \\
\hline Jumlah Peserta Didik SLTP & C5 & $20 \%$ & 0.2 \\
\hline
\end{tabular}

Berikut di bawah ini adalah pembobotan keputusan berdasarkan nilai kepentingan

\begin{tabular}{|l|c|c|}
\hline \multicolumn{3}{|c|}{ Bobot Nilai Kepentingan } \\
\hline Jarak & $\mathrm{C} 1$ & Benefit \\
\hline Luas Wilayah & $\mathrm{C} 2$ & Cost \\
\hline Jumlah SLTP & $\mathrm{C} 3$ & Benefit \\
\hline Biaya Transportasi & $\mathrm{C} 4$ & Cost \\
\hline Jumlah Peserta Didik SLTP & $\mathrm{C} 5$ & Benefit \\
\hline
\end{tabular}

G. Analisa Perhitungan Metode

\begin{tabular}{|l|l|l|l|l|l|}
\hline \multicolumn{5}{|c|}{ Bobot Nilai Kepentingan } \\
\hline \multirow{2}{*}{ Alternantif } & \multicolumn{5}{|c|}{ Kriteria } \\
\cline { 2 - 6 } & C1 & C2 & C3 & C4 & C5 \\
\hline
\end{tabular}




\begin{tabular}{|c|c|c|c|c|c|}
\hline A1 & 6.4 & 31.54 & 13 & 5000 & 4605 \\
\hline A2 & 11 & 49.6 & 4 & 10000 & 1466 \\
\hline A3 & 12 & 63.36 & 3 & 12000 & 810 \\
\hline A4 & 5.7 & 47.88 & 12 & 7000 & 2793 \\
\hline A5 & 11 & 48.48 & 10 & 9000 & 3181 \\
\hline A6 & 3.5 & 25.88 & 30 & 4000 & 10935 \\
\hline
\end{tabular}

H. Perhitungan dengan metode WP

- Perbaikan bobot $\Sigma \mathrm{W}=1$

$$
\begin{gathered}
W_{j}=\frac{W_{j}}{\sum W_{j}} \\
W_{1}=\frac{0.3}{1}=0.3 \\
W_{4}=\frac{0.2}{1}=0.2 \\
W_{3}=\frac{0.2}{1}=0.2 \\
W_{9}=\frac{0.1}{1}=0.1 \\
W_{5}=\frac{0.2}{1}=0.2
\end{gathered}
$$

\begin{tabular}{|c|c|c|c|c|c|c|c|c|c|}
\hline $\mathrm{rt} . \mathrm{I}$ & D. 5.3 & 11.2 & 0.82 & 513 & 0.43 & 11.4 & 0.80 & $\mathrm{rt} S$ & 0.42 \\
\hline 12.1 & 0.92 & 12.2 & 0.52 & 12.3 & 0.1 .3 & 12.4 & 10.40 & 12.5 & 0,13 \\
\hline ts.1 & 100 & 332 & 0,41 & 13.3 & 0.10 & 13.4 & 0.33 & 13.5 & 0,07 \\
\hline 1.4.1 & $18=8$ & 14.2 & 0.54 & 14.3 & $0.4 \mathrm{~V}$ & $r 4.4$ & 0.57 & r. 1.5 & 0.26 \\
\hline 15.1 & 092 & 55.2 & 0.53 & 153 & 0.33 & I5,4 & 0.44 & t5.5 & 0.29 \\
\hline t6. 1 & 0.29 & 16.2 & 1.00 & 16.3 & 1.00 & 15.4 & 1.00 & 15.5 & 1.00 \\
\hline
\end{tabular}

- Matrix hasil normalisasi

$$
\left\{\begin{array}{lll}
0.53 & 0.820 .43 & 0.800 .42 \\
0.92 & 0.520 .13 & 0.400 .13 \\
1.00 & 0.410 .10 & 0.330 .07 \\
0.48 & 0.540 .40 & 0.570 .26 \\
0.92 & 0.530 .33 & 0.440 .29 \\
0.29 & 1.001 .00 & 1.001 .00
\end{array}\right\}
$$

- Menghitung preferensi $(\mathrm{V})$ untuk perangkingan $\mathrm{V}_{1}=$

$(0.53 * 0.3)+(0.82 * 0.2)+(0.43 * 0.2)+(0.80 * 0.1)+$ $(0.42 * 0.2)=0.58$

$\mathrm{V}_{2}=$

$(0.92 * 0.3)+(0.52 * 0.2)+(0.13 * 0.2)+(0.40 * 0.1)+$ $(0.13 * 0.2)=0.47$

$\mathrm{V}_{3}=$

$(1.00 * 0.3)+(0.41 * 0.2)+(0.10 * 0.2)+(0.33 * 0.1)+$ $(0.07 * 0.2)=0.45$

$\mathrm{V}_{4}=$

$(0.48 * 0.3)+(0.54 * 0.2)+(0.40 * 0.2)+(0.57 * 0.1)+$ $(0.26 * 0.2)=0.44$

$\mathrm{S}_{1}=\left(6.4^{0.3}\right)\left(31.54^{-0.2}\right)\left(13^{0.2}\right)\left(5000^{-0.1}\right)\left(4605^{0.2}\right)=3.37$

$\mathrm{S}_{2}=\left(11^{0.3}\right)\left(49.6^{-0.2}\right)\left(4^{0.2}\right)\left(10000^{-0.1}\right)\left(1466^{0.2}\right)=2.12$

$\mathrm{S}_{3}=\left(12^{0.3}\right)\left(63.36^{-0.2}\right)\left(3^{0.2}\right)\left(12000^{-0.1}\right)\left(810^{0.2}\right)=1.71$

$\mathrm{S}_{4}=\left(5.7^{0.3}\right)\left(47.88^{-0.2}\right)\left(12^{0.2}\right)\left(7000^{-0.12}\right)\left(793^{0.2}\right)=2.58$

$\mathrm{S}_{5}=\left(11^{0.3}\right)\left(48.48^{-0.2}\right)\left(10^{0.2}\right)\left(9000^{-0.1}\right)\left(3181^{0.2}\right)=3.02$

$\mathrm{S}_{6}=\left(3.5^{0.3}\right)\left(25.88^{-0.2}\right)\left(30^{0.2}\right)\left(4000^{-0.1}\right)\left(10935^{0.2}\right)=4.2$

- Menghitung preferensi (V) untuk perangkingan

$$
\begin{aligned}
& V_{0}-\frac{\prod_{j=1}^{\infty} y^{2}}{\prod_{-1}^{n}(n,)^{2}} \\
& V_{1}=\frac{3.3}{1.0}=0.20 \\
& V_{4}=\frac{2.1}{1.0}=0.12 \\
& V_{\mathrm{g}}=\frac{1.7}{1.0}=0.10 \\
& V_{\mathrm{q}}=\frac{2.5}{1.0}=0.15 \\
& V_{5}=\frac{3.0}{1.0}=0.18 \\
& V_{6}=\frac{9.2}{1.0}=0.25
\end{aligned}
$$

\section{Perhitungan dengan metode SAW}

- Matrix alternatif ternormalisasi

$\mathrm{V}_{5}=$

$(0.92 * 0.3)+(0.53 * 0.2)+(0.33 * 0.2)+(0.44 * 0.1)+$ $(0.29 * 0.2)=0.55$

$\mathrm{V}_{6}=$ $(0.29 * 0.3)+(1.00 * 0.2)+(1.00 * 0.2)+(1.00 * 0.1)+$ $(1.00 * 0.2)=0.79$

\section{J. Perhitungan dengan metode TOPSIS}

- Menghitung pembagi untuk normalisasi rating kinerja setiap alternatif

$$
P_{1}=\sqrt{6.4^{2}+11^{2}+12^{2}+5.7^{2}+11^{2}+3.5^{2}}
$$

$=21.72$

$P_{2}$

$=\sqrt{31.54^{2}+49.6^{2}+63.36^{2}+47.88^{2}+48.48^{2}+25.88^{2}}$

$=113.06$

$P_{3}=\sqrt{13^{2}+4^{2}+3^{2}+12^{2}+10^{2}+30^{2}}=$ 36.58

$P_{4}$

$=\sqrt{5000^{2}+10000^{2}+12000^{2}+7000^{2}+9000^{2}+4000}$

$=20371.55$ 
$P_{5}$

$=\sqrt{4605^{2}+1466^{2}+810^{2}+2793^{2}+3181^{2}+10935^{2}}$

$$
=12708.47
$$

- $\quad$ Matrix ternormalisasi

- $\mathrm{M}$

\begin{tabular}{|l|l|l|l|l|}
\hline \multicolumn{5}{|c|}{ Matriks Ternormalisasi } \\
\hline 0.29 & 0.28 & 0.36 & 0.25 & 0.36 \\
\hline 0.51 & 0.44 & 0.11 & 0.49 & 0.12 \\
\hline 0.55 & 0.56 & 0.08 & 0.59 & 0.06 \\
\hline 0.26 & 0.42 & 0.33 & 0.34 & 0.22 \\
\hline 0.51 & 0.43 & 0.27 & 0.44 & 0.25 \\
\hline 0.16 & 0.23 & 0.82 & 0.20 & 0.86 \\
\hline
\end{tabular}

$\mathrm{n}$

ilai terbobot

\begin{tabular}{|c|c|c|c|c|c|c|c|c|c|}
\hline tb1.1 & 0.09 & tol.2 & 0,06 & thl.3 & 0.07 & to 1,4 & 0.02 & to 1.5 & 0.07 \\
\hline th 2.1 & 0.15 & th 2.2 & 0.09 & th 2.3 & 0.02 & ith 2.4 & 0.09 & $\operatorname{th} 2.5$ & 0.02 \\
\hline th 3.1 & 0.17 & th 3.2 & 0.11 & th 3.3 & 0.02 & th.3,4 & 0.06 & th 3.5 & 0.01 \\
\hline tb. 1 & 0.08 & to. 4.2 & 0,08 & tb 4.3 & 0.07 & to 4,4 & 0.03 & to 4.5 & 0.04 \\
\hline th 5.1 & 0.15 & th 5.2 & 0,09 & th 5.3 & 0,05 & th5,4 & 0,04 & to 5,5 & 0,05 \\
\hline$t b 5.1$ & 0.05 & th 6.2 & 0.05 & the 6.3 & 0.16 & th 6.4 & 0,02 & to6.5 & 0.17 \\
\hline
\end{tabular}

- Menghitung $\mathrm{Y}^{+}$dan $\mathrm{Y}^{-}$

Dengan ketentuan:

$Y_{i}^{+}-\left\{\begin{array}{c}m a x y_{i j}: j i k a j \text { adalah atribut benefit } \\ \text { ming } y_{t j}: \text { jika jadalah atribut cost }\end{array}\right.$

$\mathrm{Y}_{i}=\left\{\begin{array}{c}\max y_{i j}: \text { jika } j \text { adalah atribut cost } \\ \min y_{i j}: j \mathrm{jka} \text { j adalab atribut benefit }\end{array}\right.$

dimana:

\begin{tabular}{|c|c|c|c|c|c|c|}
\hline$Y_{\bar{t}}^{*}:$ & $\mathrm{Cl}=\mathrm{I}$ & & & : : & $\mathrm{Cl}=$ & Min \\
\hline & $C_{2}=1$ & & & & $\mathrm{C}_{2}=$ & $\operatorname{Max}$ \\
\hline & $\mathrm{C} 3=1$ & & & & $\mathrm{C} 3=$ & Min \\
\hline & $\mathrm{C} 4=1$ & & & & $\mathrm{C} 4=$ & $\operatorname{Max}$ \\
\hline & $C 5=1$ & & & & $\mathrm{Cs}=$ & Minl \\
\hline D+ & 0.16 & D. & 0.11 & pen & abagi & 0.27 \\
\hline
\end{tabular}

\begin{tabular}{|l|l|l|l|l|l|}
\hline & \multicolumn{5}{|c|}{ Matriks Terbobot } \\
\hline & 0.09 & 0.06 & 0.07 & 0.02 & 0.07 \\
\hline & 0.15 & 0.09 & 0.02 & 0.05 & 0.02 \\
\hline & 0.17 & 0.11 & 0.02 & 0.06 & 0.01 \\
\hline & 0.08 & 0.08 & 0.07 & 0.03 & 0.04 \\
\hline & 0.15 & 0.09 & 0.05 & 0.04 & 0.05 \\
\hline & 0.05 & 0.05 & 0.16 & 0.02 & 0.17 \\
\hline$y+$ & 0.17 & 0.05 & 0.16 & 0.02 & 0.17 \\
\hline$y-$ & 0.05 & 0.11 & 0.02 & 0.06 & 0.01 \\
\hline
\end{tabular}

- Jarak alternatif dengan solusi ideal positif dan negatif

$$
\begin{aligned}
& D_{i}^{+}=\sqrt{\sum_{j=1}^{n}\left(y_{i}{ }^{+}-y_{i j}\right)^{2}} \\
& D_{i}^{-}=\sqrt{\sum_{j=1}^{n}\left(y_{i j}-y_{i}^{-}\right)^{2}}
\end{aligned}
$$

- Menghitung preferensi (V) untuk perangkingan

$$
\begin{aligned}
& V_{i}=\frac{D_{i}^{-}}{D_{i}^{-}+D_{i}{ }^{+}} \\
& V_{1}=\frac{0.1}{0.2}=0.42 \\
& V_{4}=\frac{0.1}{0.3}=0.34 \\
& V_{3}=\frac{0.1}{0.3}=0.34 \\
& V_{4}=\frac{0.0}{0.2}=0.29 \\
& V_{5}=\frac{0.1}{0.2}=0.41 \\
& V_{5}=\frac{0.2}{0.3}=0.66
\end{aligned}
$$

\section{K. Proses Uji Sensitivitas}

Uji sensitivitas adalah proses mengetahui dan mendapatkan hasil dari perbandingan ketiga metode MADM, hal ini dilakukan dalam penelitian ini untuk mengetahui seberapa sensitif metode tersebut jika diterapkan pada sebuah kasus, semakin sensitif nilai yang diperoleh dari setiap perubahan ranking pada setiap metode MADM, maka metode tersebut akan semakin dipilih. Derajat sensitivitas $\left(\mathrm{S}_{\mathrm{j}}\right)$ setiap atribut diperoleh melalui langkah-langkah sebagai berikut:

1. Tentukan semua bobot atribut, $\mathrm{w}_{\mathrm{j}}=1$ (bobot awal), dengan $\mathrm{j}=1,2, \ldots$, jumlah atribut

2. Ubah bobot atribut dalam range $1-2$, serta dengan menaikkan nilai bobot sebesar 0,1 sementara bobot atribut lainnya masih tetap bernilai 1 .

3. Normalisasi bobot atribut tersebut dengan cara membentuk nilai bobot sedemikian hingga $\Sigma \mathrm{w}=1$.

4. Aplikasikan pada ketiga metode tersebut (WP, SAW, dan TOPSIS) untuk bobot-bobot atribut yang telah dibentuk pada langkah 3 .

5. Hitung persentase perubahan ranking dengan cara membandingkan berapa banyak perubahan rangking yang terjadi jika dibandingkan dengan kondisi pada saat bobotnya sama (bobot $=1$ ).

Hasil akhir ketiga metode sebelum dilakukan uji sensitivitas dapat dilihat pada tabel di bawah ini. 


\begin{tabular}{|c|c|c|c|}
\hline & WP & SAW & TOPSIS \\
\hline V1 & 0.20 & 0.58 & 0.42 \\
\hline V2 & 0.12 & 0.47 & 0.34 \\
\hline V3 & 0.10 & 0.45 & 0.34 \\
\hline V4 & 0.15 & 0.44 & 0.29 \\
\hline V5 & 0.18 & 0.55 & 0.41 \\
\hline V6 & 0.25 & 0.79 & 0.66 \\
\hline MAX & 0.25 & 0.79 & 0.66 \\
\hline
\end{tabular}

Adapun bobot (w) yang digunakan untuk setiap kriteria adalah $0.3,0.2,0.2,0.1,0.2$

Untuk melakukan uji sensitivitas ini selanjutnya bobot (w) pada setiap kriteria dinaikkan 0.5 dan 1 , dimulai dari kriteria C1 dengan menaikkan bobot 0.5 sehingga sekarang bobot (w) nya menjadi $0.8,0.2,0.2,0.1,0.2$ dan hasilnya dapat di lihat pada tabel di bawah ini:

\begin{tabular}{|c|c|c|c}
\hline & WP & SAW & TOPSIS \\
\hline V1 & 0.18 & 0.84 & 0.19 \\
\hline V2 & 0.16 & 0.93 & 0.14 \\
\hline V3 & 0.14 & 0.95 & 0.20 \\
\hline V4 & 0.15 & 0.68 & 0.18 \\
\hline V5 & 0.20 & 1.01 & 0.18 \\
\hline V6 & 0.17 & 1.29 & 0.37 \\
\hline MAX & 0.20 & 1.29 & 0.37 \\
\hline Perubahan (\%) & $-0,05 \%$ & $0.5 \%$ & $-0.29 \%$ \\
\hline
\end{tabular}

kemudian selanjutnya bobot (w) pada kriteria C1 dinaikkan 1 sehingga sekarang bobot (w) nya menjadi $\mathbf{1 . 3}$, $0.2,0.2,0.1,0.2$ dan hasilnya dapat dilihat pada tabel di bawah ini:

\begin{tabular}{|c|c|c|c}
\hline & WP & SAW & TOPSIS \\
\hline V1 & 0.17 & 1.11 & 0.18 \\
\hline V2 & 0.18 & 1.39 & 0.11 \\
\hline V3 & 0.17 & 1.45 & 0.13 \\
\hline V4 & 0.14 & 0.91 & 0.18 \\
\hline V5 & 0.21 & 1.47 & 0.13 \\
\hline V6 & 0.14 & 1.79 & 0.29 \\
\hline MAX & 0.21 & 1.79 & 0.29 \\
\hline Perubahan (\%) & $-0,04 \%$ & $1 \%$ & $-0.37 \%$ \\
\hline
\end{tabular}

Tahapan selanjutnya adalah kriteria C2 dilakukan hal yang sama yaitu menaikkan bobot 0.5 sehingga sekarang bobot (w) nya menjadi $0.3, \mathbf{0 . 7}, 0.2,0.1,0.2$ dan hasilnya dapat dilihat pada tabel di bawah ini:

\begin{tabular}{|c|c|c|c|}
\hline & WP & SAW & TOPSIS \\
\hline V1 & 0.20 & 0.99 & 0.27 \\
\hline V2 & 0.13 & 0.73 & 0.26 \\
\hline V3 & 0.10 & 0.65 & 0.27 \\
\hline V4 & 0.15 & 0.71 & 0.22 \\
\hline V5 & 0.16 & 0.82 & 0.29 \\
\hline V6 & 0.25 & 1.29 & 0.40 \\
\hline MAX & 0.25 & 1.29 & 0.40 \\
\hline Perubahan (\%) & $0 \%$ & $0.5 \%$ & $-0.26 \%$ \\
\hline
\end{tabular}

kemudian selanjutnya bobot (w) pada kriteria C2 dinaikkan 1 sehingga sekarang bobot (w) nya menjadi 0.3 ,
$1.2,0.2,0.1,0.2$ dan hasilnya dapat dilihat pada tabel di bawah ini:

\begin{tabular}{|c|c|c|c|}
\hline & WP & SAW & TOPSIS \\
\hline V1 & 0.21 & 1.40 & 0.27 \\
\hline V2 & 0.13 & 0.99 & 0.26 \\
\hline V3 & 0.10 & 0.86 & 0.25 \\
\hline V4 & 0.15 & 0.98 & 0.25 \\
\hline V5 & 0.16 & 1.08 & 0.27 \\
\hline V6 & 0.25 & 1.79 & 0.33 \\
\hline MAX & 0.25 & 1.79 & 0.33 \\
\hline Perubahan (\%) & $0 \%$ & $1 \%$ & $-0.33 \%$ \\
\hline
\end{tabular}

selanjutnya adalah kriteria $\mathbf{C 3}$ dilakukan hal yang sama yaitu menaikkan bobot 0.5 sehingga sekarang bobot (w) nya menjadi $0.3,0.2, \mathbf{0 . 7}, 0.1,0.2$ dan hasilnya dapat dilihat pada tabel di bawah ini:

\begin{tabular}{|c|c|c|c|}
\hline & WP & SAW & TOPSIS \\
\hline V1 & 0.20 & 0.79 & 0.12 \\
\hline V2 & 0.10 & 0.54 & 0.17 \\
\hline V3 & 0.08 & 0.50 & 0.20 \\
\hline V4 & 0.16 & 0.64 & 0.10 \\
\hline V5 & 0.17 & 0.72 & 0.18 \\
\hline V6 & 0.30 & 1.29 & 0.31 \\
\hline MAX & 0.30 & 1.29 & 0.31 \\
\hline Perubahan (\%) & $0.05 \%$ & $0.5 \%$ & $-0.35 \%$ \\
\hline
\end{tabular}

kemudian selanjutnya bobot (w) pada kriteria C3 dinaikkan 1 sehingga sekarang bobot (w) nya menjadi $0.3,0.2,1.2,0.1,0.2$ dan hasilnya dapat dilihat pada tabel di bawah ini:

\begin{tabular}{|c|c|c|c|}
\hline & WP & SAW & TOPSIS \\
\hline V1 & 0.19 & 1.01 & 0.08 \\
\hline V2 & 0.09 & 0.61 & 0.12 \\
\hline V3 & 0.07 & 0.55 & 0.14 \\
\hline V4 & 0,16 & 0.84 & 0.07 \\
\hline V5 & 0.16 & 0.88 & 0.12 \\
\hline V6 & 0.33 & 1.79 & 0.17 \\
\hline MAX & 0.33 & 1.79 & 0.17 \\
\hline Perubahan (\%) & $0.08 \%$ & $1 \%$ & -0.49 \\
\hline
\end{tabular}

selanjutnya adalah kriteria $\mathbf{C 4}$ dilakukan hal yang sama yaitu menaikkan bobot 0.5 sehingga sekarang bobot (w) nya menjadi $0.3,0.2,0.2, \mathbf{0 . 6}, 0.2$ dan hasilnya dapat dilihat pada tabel di bawah ini:

\begin{tabular}{|c|c|c|c|}
\hline & WP & SAW & TOPSIS \\
\hline V1 & 0.21 & 0.98 & 0.26 \\
\hline V2 & 0.12 & 0.67 & 0.26 \\
\hline V3 & 0.10 & 0.62 & 0.29 \\
\hline V4 & 0.16 & 0.72 & 0.23 \\
\hline V5 & 0.16 & 0.77 & 0.29 \\
\hline V6 & 0.26 & 1.29 & 0.40 \\
\hline MAX & 0.26 & 1.29 & 0.40 \\
\hline Perubahan (\%) & $0.01 \%$ & $0.5 \%$ & $-0.26 \%$ \\
\hline
\end{tabular}

kemudian selanjutnya bobot (w) pada kriteria C4 dinaikkan 1 sehingga sekarang bobot (w) nya menjadi $0.3,0.2,0.2, \mathbf{1 . 1}, 0.2$ dan hasilnya dapat dilihat pada tabel di bawah ini: 


\begin{tabular}{|c|c|c|c|}
\hline & WP & SAW & TOPSIS \\
\hline V1 & 0.21 & 1.38 & 0.25 \\
\hline V2 & 0.12 & 0.87 & 0.24 \\
\hline V3 & 0.10 & 0.78 & 0.25 \\
\hline V4 & 0.16 & 1.01 & 0.24 \\
\hline V5 & 0.15 & 1.00 & 0.25 \\
\hline V6 & 0.26 & 1.79 & 0.31 \\
\hline MAX & 0.26 & 1.79 & 0.31 \\
\hline Perubahan (\%) & $0.01 \%$ & $1 \%$ & $-0.35 \%$ \\
\hline
\end{tabular}

selanjutnya adalah kriteria C5 dilakukan hal yang sama yaitu menaikkan bobot 0.5 sehingga sekarang bobot (w) nya menjadi $0.3,0.2,0.2,0.1, \mathbf{0 . 7}$ dan hasilnya dapat dilihat pada tabel di bawah ini:

\begin{tabular}{|c|c|c|c}
\hline & WP & SAW & TOPSIS \\
\hline V1 & 0.20 & 0.79 & 0.12 \\
\hline V2 & 0.10 & 0.54 & 0.16 \\
\hline V3 & 0.07 & 0.49 & 0.19 \\
\hline V4 & 0.14 & 0.57 & 0.11 \\
\hline V5 & 0.17 & 0.70 & 0.18 \\
\hline V6 & 0.31 & 1.29 & 0.30 \\
\hline MAX & 0.31 & 1.29 & 0.30 \\
\hline Perubahan (\%) & $0.06 \%$ & $0.5 \%$ & $-0.36 \%$ \\
\hline
\end{tabular}

kemudian selanjutnya bobot (w) pada kriteria C5 dinaikkan 1 sehingga sekarang bobot (w) nya menjadi 0.3 , $0.2,0.2,0.1,1.2$ dan hasilnya dapat dilihat pada tabel di bawah ini:

\begin{tabular}{|c|c|c|c|}
\hline & WP & SAW & TOPSIS \\
\hline V1 & 0.20 & 1.00 & 0.07 \\
\hline V2 & 0.09 & 0.61 & 0.11 \\
\hline V3 & 0.06 & 0.52 & 0.13 \\
\hline V4 & 0.14 & 0.69 & 0.07 \\
\hline V5 & 0.16 & 0.84 & 0.11 \\
\hline V6 & 0.35 & 1.79 & 0.17 \\
\hline MAX & 0.35 & 1.79 & 0.17 \\
\hline Perubahan (\%) & $0.10 \%$ & $1 \%$ & $-0.49 \%$ \\
\hline
\end{tabular}

Dari hasil diatas dapat dilihat summary perubahan ranking dengan Metode WP, SAW, dan TOPSIS dalam kasus ini :

\begin{tabular}{|c|c|c|c|}
\hline Kriteria & WP & SAW & TOPSIS \\
\hline Kriteria $1+(0.5)$ & $-0.05 \%$ & $0.5 \%$ & $.0 .29 \%$ \\
\hline Kriteria 1+(1) & $-0.04 \%_{4}$ & $1 \%$ & $-0.37 \%$ \\
\hline Kriteria $2+(0.5)$ & $0 s$ & $0.5 \%$ & $-0.26 \%$ \\
\hline Kriteria 2+(1) & $0 \%$ & $1 \%$ & $-0,33 \%$ \\
\hline Kriteria $3+(0.5)$ & $0.05 \%$ & $0.5 \%$ & $-0.35 \%$ \\
\hline Kriteria $3+(1)$ & $0.08 \%$ & $1 \%$ & $-0.49 \%$ \\
\hline Kriteria $4+(0.5)$ & $0.01 \%$ & $0.5 \%$ & $-0.26 \%$ \\
\hline Kriteria $4+(1)$ & $0.01 \%$ & $1 \%$ & $-0.35 \%$ \\
\hline Kriteria $5+(0.5)$ & $0.06 \%$ & $0.5 \%$ & $-0.36 \%$ \\
\hline Kriteria $5+(1)$ & $0.10 \%$ & $1 \%$ & $-0.49 \%$ \\
\hline Jumlah & $0.94 \%$ & $7.5 \%$ & $-3.55 \%$ \\
\hline
\end{tabular}

\section{KESIMPULAN}

Berdasarkan hasil penelitian dan pembahasan akhirnya dapat disimpulkan bahwa :

1. Dengan penelitian ini dapat menyelesaikan kasus dengan metode WP, SAW dan TOPSIS, dengan cepat dan akurat.
2. Dengan adanya proses uji sensitivitas pada sistem ini,

dapat diketahui metode yang paling relevan dengan kasus disini adalah SAW, dengan perubahan SAW sebesar 7,5\%, TOPSIS sebesar $-3.55 \%$ dan WP sebesar $0.94 \%$.

Uji Sensitivitas Metode Wp, Saw Dan Topsis Dalam Menentukan Titik Lokasi Repeater Internet Wireless

\section{REFERENSI}

[1] Sri Eniyati, Perancangan Sistem Pendukung Pengambilan Keputusan untuk Penerimaan Beasiswa dengan Metode SAW (Simple Additive Weighting), Jurnal Teknologi Informasi DINAMIK Volume 16, No.2, Juli 2011 : 171- 176, ISSN : 0854- 9524

[2] Nuri Guntur and Widodo, Tri (2013) Sistem Pendukung Keputusan Pemberian Beasiswa Kepada Peserta Didik Baru Menggunakan Metode TOPSIS, Seminar Nasional Teknologi Informasi \& Komunikasi Terapan ISBN: 979-26-0266-6

[3] Nency Nurjannah, Zainal Arifin, Dyna Marisa Khairina, (2015), Sistem Pendukung Keputusan Pembelian Sepeda Motor Dengan Metode Weighted Product, Jurnal Informatika Mulawarman.

[4] David Ahmad Effendy, Rony Heri Irawan, (2015), "Uji Sensitivitas Metode Wp, Saw Dan Topsis Dalam Menentukan Titik Lokasi Repeater Internet Wireless", Seminar Nasional Teknologi Informasi dan Multimedia 2015 